\title{
Incidence and morphometric analysis of Metoptic Canal and Warwick's Foramen in South Indian Skulls
}

\author{
Shabbarish Chockalingam ${ }^{1}$ and Yuvaraj Babu K ${ }^{2}$ \\ ${ }^{1}$ Saveetha Dental College and Hospitals, Saveetha Institute of Medical and \\ Technical Sciences, Saveetha University, Chennai- 600077 India \\ ${ }^{2}$ Assistant Professor, Department of Anatomy, Saveetha Dental College \&t Hospitals, Saveetha \\ institute of Medical and Technical Sciences, Saveetha University, Chennai - 600077, India
}

\begin{abstract}
The human orbit is related to the cranial cavity through several canals and some of which can be found in every human orbit such as the optic canal and the superior orbital fissure and there are some which cannot be found in every orbit such as the Met-optic Canal and the Warwick's Foramen. Minor canals have often been a nuisance to surgeons as they often have an artery or a vein passing through them and hence are known to have caused severe bleeding making the surgeon's job all the more harder. In this study, we find the incidence of these minor canals and we take the morphometric measurements to three structures in South Indian skulls. It was found that on average, it appeared on both the right and the left orbits and its average distance was found and the results were compared that of other studies. In conclusion, the prior knowledge of these canals will undoubtedly give surgeons an advantage while performing such procedures.
\end{abstract}

\section{KEY WORDS: METOPTIC CANAL, WARWICK'S FORAMEN, ORBIT, MINOR ORBITAL CANAL.}

\section{INTRODUCTION}

The human orbit is a pyramid shaped cavity that is situated on either side of the root of the nose. The orbit itself resembles a 4 sided pyramid with the apex at the posterior end and the base of the orbit opening into the face. It is related to the greater wing of sphenoid and the lesser wing of sphenoid, zygomatic bone, maxillary, sphenoidal and frontal sinuses It's related to the cranial cavity by both major and minor canals. Major canals connecting the orbit to the cranial cavity include the optic canal and the superior orbital fissure. These canals are also known as major canals because they are found in

\section{ARTICLE INFORMATION}

*Corresponding Author: yuvarajbabu@saveetha.com Received 4th Aug 2020 Accepted after revision 26th Sep 2020 Print ISSN: 0974-6455 Online ISSN: 2321-4007 CODEN: BBRCBA

Thomson Reuters ISI Web of Science Clarivate Analytics USA and Crossref Indexed Journal

\section{Clarivate
Analytics}

NAAS Journal Score 2020 (4.31) SJIF: 2020 (7.728)

A Society of Science and Nature Publication,

Bhopal India 2020. All rights reserved.

Online Contents Available at: http//www.bbrc.in/

Doi: http://dx.doi.org/10.21786/bbrc/13.8/135 every human orbit, while on the other hand minor canals do not appear in every human orbit and hence they are not documented as frequently as major canals (Diamond, 1991). Two such structures which are focused on in this study are the Metoptic canal and Warwick's Foramen.

The Metoptic canal is found between the Superior Orbital Fissure and the Optic Canal, such structures that are a result of variations to the optic canal are rare(Choudhry $\mathrm{R}$ et $\mathrm{al}, 1988$ ) while the optic canal is usually round in shape (Radoievitch and Jovanovic, 1960). The contents passing through the canal include the ophthalmic artery and the ophthalmic nerve $(R, 1951)$. The formation of the met optic canal is because of a difference in the pattern of ossification. It is a defect that occurs during the process of ossification that sometimes ossifies in the shape of a keyhole (R, 1951).

While this generally does not cause an issue because within a few months, generally 2 months, after birth, the ossification processes result in the keyhole shaped canal becoming a more recognisable round shape, these 
structures are known to have helped with childbirth (Rogith Kannan and Thenmozhi, 2017) even though there have been cases where the canals were closing at about 6 years of age. But sometimes, the ophthalmic vessels descend to the bottom of the keyhole and the bone ossifies around the artery. Thus resulting in the formation of the Met-optic canal (Lang, 1977). Other than the ophthalmic artery, some minor vessels have been documented to be passing through this canal.

Warwick's Foramen on the other hand are far more rare, hence they are rarely accounted for. Which means that we have not had sufficient evidence for the development of the Foramen. It is located in the cranial cavity, between the Superior Orbital Fissure and the Foramen Rotundum (Bisaria et al., 1996). It has not been studied enough, but it has been hypothesized that the Inferior Orbital Vein passes through it. The rarity of its occurrence was evident some studies finding the occurrence to be less than 1\% (Bertelli, 2014).

Previously our department has published extensive research on various aspects of dentistry (Begum et al, 2017; Ganapathy, Kannan and Venugopalan, 2017; Jain, 2017a, 2017b; Ranganathan, Ganapathy and Jain, 2017; Ariga et al., 2018; Gupta, Ariga and Deogade, 2018; Anbu et al., 2019; Ashok and Ganapathy, 2019; Duraisamy et al., 2019; Varghese et al., 2019), this vast research experience has inspired us to research about the incidence and the morphological analysis of Met-optic Canal and Warwick's Foramen. This study was chosen because of the fact that these structures are not commonly found and thus have caused surgeons problems of excessive bleeding during procedures involving the human orbit or the cranial cavity. The very knowledge of the presence of these structures would help surgeons deal with the issue effectively. The aim of this study was to determine the incidence of Metoptic Canal and Warwick's Foramen and perform its morphometric measurements in South Indian skulls.

\section{MATERIAL AND METHODS}

36 unsexed adult human skulls were obtained from the Department of Anatomy, Saveetha Dental College, out of which 4 were discarded due to damage. All the 32 skulls obtained were of the South Indian origin and were all cranial cavity specimens. They were observed for the incidence of the Metoptic canal and Warwick's Foramen. If they were present, their morphometric analysis was taken.

Table 1 . Distance of 4 metoptic canals from anatomical landmarks in orbit

\begin{tabular}{|l|c|c|c|c|}
\hline S. No & $\begin{array}{c}\text { Presence of } \\
\text { Met-Optic } \\
\text { canal }\end{array}$ & $\begin{array}{c}\text { Distance from } \\
\text { Fronto-Zygomatic } \\
\text { Suture }\end{array}$ & $\begin{array}{c}\text { Distance from } \\
\text { Supraorbital Notch }\end{array}$ & $\begin{array}{c}\text { Distance from } \\
\text { Whitnall's } \\
\text { Tubercle }\end{array}$ \\
\hline 1 & Right & $4.8 \mathrm{~cm}$ & $4.4 \mathrm{~cm}$ & $4.6 \mathrm{~cm}$ \\
\hline 2 & Left & $6.5 \mathrm{~cm}$ & $6 \mathrm{~cm}$ & $5.4 \mathrm{~cm}$ \\
\hline 3 & Right & $5.7 \mathrm{~cm}$ & $5.7 \mathrm{~cm}$ & $5.4 \mathrm{~cm}$ \\
\hline 4 & Right & $4.8 \mathrm{~cm}$ & $5 \mathrm{~cm}$ & $4.6 \mathrm{~cm}$ \\
\hline & Average & $5.45 \mathrm{~cm}$ & $5.27 \mathrm{~cm}$ & $5 \mathrm{~cm}$ \\
\hline
\end{tabular}

Figure 1: White arrows indicates the Metoptic canal, Optic Canal and the Superior Orbital Fissure in the Left orbit

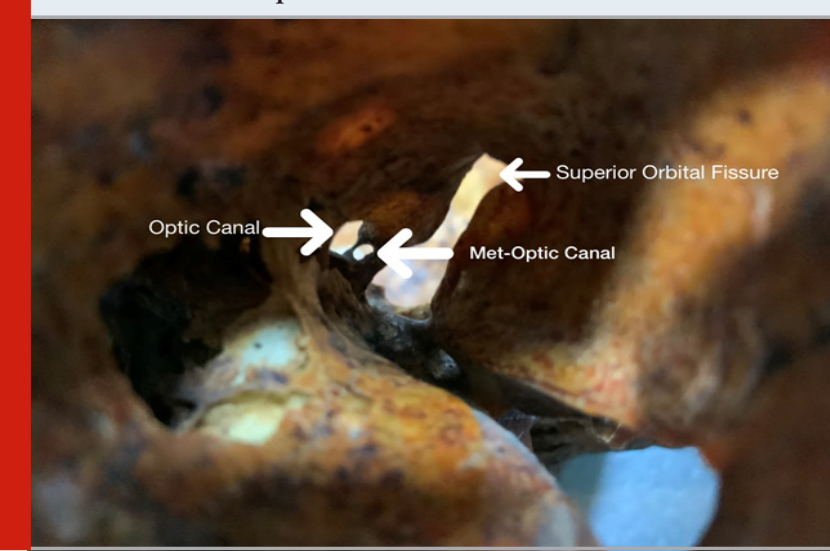

For the Metoptic canal, the distances were measured from the base of the metoptic canal to the following structures
- Whitnall's Tubercle

- Frontozygomatic Suture

- Supraorbital notch

These structures were chosen because of the ease of access to these structures with the measuring instruments at hand. The instruments used were a thick wire which was used for the measurement of the distance and a syringe which helped in anchoring the wire to the bone. One of the skulls observed had an optic canal in the shape of a keyhole, which further strengthens the theory of the formation of the metoptic canal.

\section{RESULTS AND DISCUSSION}

32 skulls were examined, totalling up to 64 orbits, of these there were only 4 orbits that had incidences of the metoptic canal, 3 were found on the right orbit and 1 was found on the left and Warwick's Foramen was not found in any of the orbits. 
In this study, there were only 4 metoptic canals found out of a total of 64 orbits examined. Fig. 1 shows a Metoptic Canal found in one of the skulls, while it is unusual for a canal to be as big as it is shown. Three of which were found on the right and the remaining 1 was found on the left. In total, that sums up to $7.8 \%$ of all the cranial cavities examined had a met-optic canal. Another fact to be noted is that of all the skulls that were found to have Met-optic canals, all were found to be unilateral. In addition to that, Warwick's Foramen was not found in any of the 64 orbits examined. This lack of formation of the Warwick's Foramen could be indicative of the fact that this foramen does not ossify in the South Indian skull as there were no prior records or studies that have observed this.

Issues pertaining to accessibility and the lack of advanced means of measurement, we had to use simpler means of measurement which was the aforementioned thick piece of wire inserted into the syringe that was used as a measuring tool, there were measures taken to ensure the accuracy of the results such as not using the same wire twice and rechecking the length twice. The Warwick's Foramen found in the cranial cavity is consistent with the findings of Bertelli who found Warewick's Foramen in just $0.74 \%$ out of 2566 orbits and less so with Arzus Hizay's findings of $9.7 \%$ out of 92 skulls. Even the incidence of Met-optic canal is closer to the findings of Bertelli Ethan to Arzu Hizay (Hizay et al., 2019). The study by K.K. Bisaria, found that the side of incidence of the Warwick's Foramen and in turn minor canals were not dependent on sex and this was supported by my findings (Bisaria et al., 1996).

\section{CONCLUSION}

This study shows Metoptic Canal was present in 7.8\% of skulls examined,. This study was chosen because of the fact that Metoptic canal and Warwick's Foramen are not commonly found in the orbit and can cause problems of excessive bleeding during surgical procedures involving the human orbit or the cranial cavity.

\section{ACKNOWLEDGEMENTS}

We acknowledge the Department of Anatomy, Saveetha Dental College for allowing us to use the bones from their collection for this study.

Conflict of Interest: The authors reported the conflict of interest while performing this study to be nil.

\section{REFERENCES}

Ajrish George S et al (2015) Study of Occurance of Metopic Suture in Adult South Indian Skulls /J. Pharm. Sci. \&t Res. Vol. 7(10), 904-906

Anbu, R. T. et al. (2019) 'Comparison of the Efficacy of Three Different Bone Regeneration Materials: An Animal Study', European journal of dentistry, 13(1), pp. 22-28.

Ariga, P. et al. (2018) 'Determination of Correlation of
Width of Maxillary Anterior Teeth using Extraoral and Intraoral Factors in Indian Population: A Systematic Review', World Journal of Dentistry, 9(1), pp. 68-75. Ashok, V. and Ganapathy, D. (2019) 'A geometrical method to classify face forms', Journal of oral biology and craniofacial research, 9(3), pp. 232-235.

Begum R, Ariga P, Ashish Jain'Evaluation of Corrosive Behavior of Four Nickel-chromium Alloys in Artificial Saliva by Cyclic Polarization Test:An in vitro Study' (2017) World Journal of Dentistry, 8(6), pp. 477-482. Bertelli, E. (2014) 'Metoptic canal, duplication of the optic canal and Warwick's foramen in human orbits', Anatomical Science International, pp. 34-45. doi: 10.1007/s12565-013-0197-7.

Bisaria, K. K. et al. (1996) 'An accessory foramen deep in the infraorbital fissure', Journal of anatomy. WileyBlackwell, 189(Pt 2), p. 461.

Choudhry R, Choudhry S, Anand C. Duplication of optic canals in human skulls. J Anat. 1988;159:113-116.

Diamond, M. K. (1991) 'Homologies of the stapedial artery in humans, with a reconstruction of the primitive stapedial artery configuration of euprimates', American Journal of Physical Anthropology, pp. 433-462. doi: 10.1002/ajpa.1330840408.

Duraisamy, R. et al. (2019) 'Compatibility of Nonoriginal Abutments With Implants: Evaluation of Microgap at the Implant-Abutment Interface, With Original and Nonoriginal Abutments', Implant dentistry, 28(3), pp. 289-295.

Ganapathy, D. M., Kannan, A. and Venugopalan, S. (2017) 'Effect of Coated Surfaces influencing Screw Loosening in Implants: A Systematic Review and Meta-analysis', World Journal of Dentistry, 8(6), pp. 496-502.

Gupta, P., Ariga, P. and Deogade, S. C. (2018) 'Effect of Monopoly-coating Agent on the Surface Roughness of a Tissue Conditioner Subjected to Cleansing and Disinfection: A Contact Profilometric Study', Contemporary clinical dentistry, 9(Suppl 1), pp. S122S126.

Hizay, A. et al. (2019) 'Metoptic Canal and Warwick's Foramen: Incidence and Morphometric Analysis by Several Reference Points in the Human Orbit', The Eurasian Journal of Medicine, pp. 1-4. doi: 10.5152/ eurasianjmed.2018.17353.

Jain, A. R. (2017a) 'Clinical and Functional Outcomes of Implant Prostheses in Fibula Free Flaps', World Journal of Dentistry, 8(3), pp. 171-176.

Jain, A. R. (2017b) 'Prevalence of Partial Edentulousness and Treatment needs in Rural Population of South India', World Journal of Dentistry, 8(3), pp. 213-217. Lang, J. (1977) 'Structure and postnatal organization of heretofore uninvestigated and infrequent ossifications 
of the sella turcica region', Acta anatomica, 99(2), pp. 121-139.

Radoievitch, S. and Jovanovic, S. (1960) '[Relations of the optic canal of children to the posterior paranasal sinuses (contribution to the development of the sphenoid sinus)]', Acta anatomica, 41, pp. 172-183.

Ranganathan, H., Ganapathy, D. M. and Jain, A. R. (2017) 'Cervical and Incisal Marginal Discrepancy in Ceramic Laminate Veneering Materials: A SEM Analysis', Contemponorary clinical dentistry, 8(2), pp. 272-278.

R, W. (1951) 'A Juvenile Skull Exhibiting Duplication of the Optic Canals and Subdivision of the Superior Orbital Fissure', Journal of anatomy. J Anat, 85(3). Available at: https://pubmed.ncbi.nlm.nih.gov/14850397/ (Accessed: 1 July 2020).

Rogith Kannan and Thenmozhi M.S, Study of incidence of Metopic suture in adult skulls | International Journal of Current Research, Vol. 9, Issue 08, pp.56429-56431 Varghese, S. S., Ramesh, A. and Veeraiyan, D. N. (2019) 'Blended Module-Based Teaching in Biostatistics and Research Methodology: A Retrospective Study with Postgraduate Dental Students', Journal of dental education, 83(4), pp. 445-450. 